\title{
The South African Poultry Industry is in Dire Straits and is Facing Collapse: Is it a Management and Political Issue
}

\begin{abstract}
Anis Mahomed Karodia
Senior Academic and Researcher at the Regent Business School, Durban, Republic of South Africa

Abstract: The paper looks at the reasons as to why the South African poultry industry is in a flap and, in a state of collapse. Should South Africa shut down dumped chicken imports to prevent industry collapse, despite the fact that the European Union (EU) cries foul over the chicken crisis claims. On the other hand the South African poultry industry cries foul because of the status of import duties on poultry. The paper will look at these issues with an open mind and also argues that higher import duties will not fix all of the South African poultry sectors problems. It highlights very briefly the Trade and Industry Minister's statement that chicken farmers are at risk. In so doing other important issues will be introduced within the narrative. It must be highlighted that the South African poultry industry is one of the most sophisticated industries on the continent of Africa, and therefore analyses some of the causes for this sudden demise. This collapse of the poultry industry is very significant in a country that is battling to curb its unemployment woes due to very serious problems within its very sluggish economy and the massive retrenchments within the industry. This is the reality that confronts the country and indeed solutions must be found to deal with this vexing issue. The paper will therefore nuance some of these issues. In the conclusion to this narrative, the author will argue that the fundamental structure of the South African economy must change in order to bring about delivery of services and deal with many of the issues that confront the country in terms of general development. The paper argues that the fundamental structure of the South African economy must change. Conclusions and recommendations are made throughout the discussion and at the end of the paper a dedicated discussion is undertaken in respect of some of the recommendations and conclusions that are provided.
\end{abstract}

Keywords: Poultry, Challenges, European Union, Economy, Unemployment, Collapse, Industry, Dumped Chicken, Imports, Duties, Risk, Structure

\section{Methodology of the Paper}

The paper does not use classical research methodology to compile this paper. This is obvious because the paper entails critical analysis of the issues used by the author. In addition, articles from the popular South African press will be used, in order to situate the subject matter, in order to give the paper some structure and in order to bolster the critique of the content of the paper. Such an approach in no way dilutes the thrust of the paper, in terms of the essential arguments contained in the narrative. On the other hand the paper does not lend itself to the use of the classical research approach. This approach is not a fundamental limitation to the discussion undertaken. The paper therefore talks to the salient issues that encompass the near collapse of the South African poultry industry. It is an important paper, in the sense that the discussion is important, in terms of its critique and analysis, as concerns the problems and challenges that need to be addressed by both government and the poultry industry of South Africa. Recommendations and conclusions are dispersed throughout the narrative and a dedicated discussion on the recomme4ndations and conclusions is undertaken at the end of the paper.

\section{INTRODUCTION}

The old adage that the chickens have come home to roost for South Africa's poultry industry, holds true at the current stage of its development. It faces total collapse. After years of negligence and in the face of the flood of cheaper chicken imports from some European Union (EU) countries and Brazil, the local industry has finally buckled in, throwing thousands of workers onto the streets. The drought ravaging the country has also added to the woes of poultry farmers, chicken feed and other essential and important inputs have become too expensive for many of the players to run profitable businesses. 
The Editor (The Mercury, 2017:6) states that "Rainbow Chicken, one of the major companies, says it retrenched 1200 workers, a week ago (January, 2017) and that, this will increase within Rainbow and other chicken establishments in the country. The situation is precarious and is causing much hardship to workers and, this position will further deteriorate in a very poor economic climate. Rainbow has sold 15 of its 25 poultry farms to stay afloat. For thousands of workers to lose their jobs at a time when economic growth is stagnant and, job losses across the country are at an all - time high is nothing short of a disaster. The South African poultry industry is in dire stress and in an absolute crisis."

The blame games are in full swing, some blaming the cheaper imports, others blaming government for not seeing the crisis coming; we need to make sure that other sectors of South African agriculture and food industry also do not follow the same path. The collapse of the poultry industry suggests the South African poultry industry is not ready to compete with countries like Brazil and other countries. Government needs to assist struggling producers not only in the poultry sector; but in the entire agriculture industry. Otherwise, some industries will be wiped out and food security will be at risk.

While politicians play games and suggest that government should take over poultry farms to save jobs and shield the industry from total collapse, they fail to address the reasons why the country is in this mess in the first place. South African farmers cannot compete globally without subsidies. The chorus that supports the move that government buys of the poultry industry is a populist move by the trade union movement and, indeed the African National Congresses' Youth League. This might be a short sighted move because South Africa engages the capitalist system of production and, any move to move in the direction of populist initiatives to wrest control of the poultry sector will exacerbate the situation. It may be a short term solution and eventually will lead to a frightening collapse of the industry. Government just does not have the wherewithal to run a multibillion industry and the complexities involved in the make - up of the poultry industry. There will also be massive interference by the trade movement industry and eventually the South African poultry industry will be lowered to the lowest common denominator (Read the collapse of industries in Venezuela under President Hugo Chavez). This will make its emergence again almost well - nigh impossible and, will spell the death knell of a mature and significant industry that took decades to construct and build. The answer to this vexing, pressurized highly charged political issue is that government must move in and subsidize our poultry farmers and the commercial poultry industry.

Further, to save jobs and keep the poultry industry afloat, it might be necessary to revisit some trade agreements that the country has signed previously under a different economic trajectory. This will help find a balance between saving jobs and cheaper food for millions of people facing inflation and the rising cost of living (The Mercury, 2017:6). South Africans have to live in the hope that the African National Congress as the ruling party, will come up with viable solutions to save the poultry industry and help the jobs bloodbath. It is under this background that the author will further elaborate the discussion and narrative to look at the issues that confront the poultry industry of South Africa. In fact all industries and its lack of industrialization programme.

\section{ChICKen FARMERS AT RISK - DAVIES}

Kevin Crowley reports that the Minister of Trade and Industry Rob Davies said that "South Africans must defend its chicken farmers from an influx from Europe or face the collapse of the local industry. While domestic producers must become more competitive to ensure the industry's sustainability, their efforts will be useless unless cheap imports were stemmed." However, the Minister does not present any tangible solutions in terms of government intervention. In other words it is grandstanding and more of the same rhetoric, in spite of farmer and poultry industry representation to government.

Since tariffs were removed five years ago under a trade agreement between Europe and South Africa, imports of bone - in portions, such as legs and thighs, have tripled to more than 188 million kilograms last year, according to the poultry association (Kevin Crowley (2017:18). The competitive issues will always be present but the big question is, as to how the government and, the poultry sector will work around those issues that hold the poultry industry to ransom. There is no doubt that if the government, its Trade and Industry Ministry and the farmers together with the poultry industry do not act decisively, the problems and challenges would not be resolved, if the influx of spare parts from around the world comes in and takes over the South African poultry market. Crowley (2017:18) states that "South African farmers and producers say that they are being unfairly undercut by imported bone 
- in portions after tariffs on chicken from Europe were removed at the start of 2012. European consumers' preference for chicken breasts means the continent's producers have an abundance of legs, thighs and wings that they can sell cheaply in Africa." There is definitely distress and there can be no doubt about this.

After South Africa imposed a temporary 13.9 percent duty on European imports, in December of 2016, EU Trade Commissioner Cecilia Malmstrom wrote to Davies saying that South Africa's 'structural problems' were more to blame for the local poultry industry's problems than competition from Europe (Kevin Crowley, 2017:18). What then is the stance of the EU in this regard?

\section{EU Cries Foul over Chicken Crisis Claims}

The EU says that the link between imports from the bloc and alleged disturbances in the South African chicken market is not clearly established, especially in relation to two years of drought in South Africa, reports Mark Allix (2017:10). On the other hand South African producers and the Food and Allied Workers Union have criticized the Department of Trade and Industry, saying that it is doing nothing while thousands of workers are losing their jobs, mainly because of EU imports. However, the EU in terms of its many statements on this issue has said that, it appears that there has been no real consideration of the jump in local feed costs in 2016, given the poor economic climate in the country. The EU further adds in its various communiqués' that 75 percent of the cost of raising a chicken goes to feed costs and, if this is coupled with inefficiencies hampers the competitiveness of South African producers. The author being a former state veterinarian and having worked on poultry farms and poultry abattoirs in South Africa concurs with the European viewpoint. In this regard Massimo De Luca head of trade and economics at the delegation of the EU to South Africa as reported by Mark Allix (2017:10) states that "There can be little doubt that the cost of chicken in South Africa has been negatively impacted by the recent drought and amidst other factors, such as the quality of imported chicken, might also play a role."

De Luca (In Mark Allix, 2017) emphasizes that "on December 15, South Africa imposed a provisional safeguard duty of 13.9 percent on chicken imported from the EU. This affects all imports of frozen bone - in portions of chicken imported from the Netherlands, Germany and Britain. The South African Department of Trade and industry says that the duty will provide an opportunity to find a mutually agreed solution with the EU." The agreed solution is not outlined by the department and what is required is more than one independent study to assess the depth of the crisis because the EU agreement will be in force until July 3 of 2017 . What will be the situation there after is left to be seen. There is no doubt that nothing will change drastically unless the government of South Africa is prepared to bite the bullet and subsidize South African producers. If this route is followed, there will be a hue and cry from the EU countries and Brazil and, if not well negotiated can spell further disaster for the South African poultry industry and other sectors importing and exporting products to the EU.

Mark Allix states that "The import duty on a number of poultry products from countries including Brazil and the US was increased significantly to 82 percent for whole birds; 31 percent for carcasses; 12 percent for boneless cuts; and 37 percent for bone - in portions." This is not the true picture because duties are not applicable to EU imports as South Africa has a preferential trade agreement with the bloc. It's the EU imports that is undertaken legally and South Africa is therefore in a quagmire and, thus EU chicken portions continue to flood the South African market that cannot compete with EU countries in terms of price. Allix (2017:10) further reports that "In 2015, however, anti - dumping measures ranging from 3.86 percent to 73.33 percent were imposed on frozen bone in pieces from Germany, Netherlands and the United Kingdom." This does not resolve the issues in respect of all EU countries that export to South Africa and also dump their cheap products into the South African poultry market.

The EU according to Mark Allix says that "There has been an investigation by SA's International Trade Administration Commission (Itac) into the alleged dumping of EU chicken since 2013 and that the EU position will be presented to Itac. And in October of 2016, an Economic partnership Agreement (EPA) came into force between the EU and the Southern African Development Community, providing for better market access for agricultural products. This is the nub of the issue that South Africa has to understand rather than crying foul, as it engages with the capitalist order of Western countries within the EU by virtue of agreements entered into with these countries via the 
European Union. Against this background new trade defence measures that limit market access to the other party's market are to be subject to discussions, in a special trade and development committee to be convened under the EPA agreement. In the same vein, it appears that the impact of South Africa's poultry industry bringing practices on consumer choice has not been thoroughly assessed," according to Luca (In Mark Allix, 2017:10).

The issue of brining touches a nerve in South Africa's poultry industry. This is a universal practice of injecting salty and often spicy water into the chicken for purposes of making the chicken more succulent but, by the same token short changing the consumer in terms of actual weight of the chicken. According to Allix (2017:10) "South Africa is accused of injecting 40 percent of brine into chicken products. Critics say this means consumers are paying for salty water rather than chicken. New regulations impose a cap of 15 percent brine on individually quick - frozen portions and 10 percent on whole birds. Some countries like Brazil, ban brining entirely. Others limit it to 8 percent of a chicken's weight," These are some of the real issues that confront the poultry industry throughout the world and, it is thus a question has to how countries deal with these issues.

\section{The South African Position as the Poultry Industry Cries Foul In RELATIONSHIP OF THE STATUS OF IMPORT DUTIES}

For more than three years now, the South African poultry industry has cried foul over the import duties charged on foreign poultry products. These import duties have come under scrutiny due to the surge in imports of foreign products, as well as the alleged dumping of poultry in the South African market, which has resulted in some local poultry producers announcing major retrenchments. In response, the Department of Trade and Industry (DTI), in conjunction with the Department of Agriculture, Forestry and Fisheries, has been working with domestic poultry producers to address these challenges. It must be appreciated that the demand for bone - in portions of chicken is relatively non - existent in the EU, making it more of a by - product for EU producers who can therefore sell bone - in chicken portions to the South African market at a reduced cost. The South African market has a high demand for bone - in chicken portions. In this regard Shepstone and Wylie Attorneys (2017:7) point out that "In addressing local poultry industry grievances in 2013 , the import duty on several poultry products was significantly increased. In respect of the various duties imposed the EU Ambassador Marcus Cornaro has recently dismissed the allegations that European exporters are dumping bone - in chicken on to the South African market and, further pointed out that the prices of frozen chicken pieces from Belgium, Ireland and Spain are not the cheapest on the market and that imports from the Netherlands, France, Germany, the UK, Hungary, Poland and Denmark are currently prohibited, due to the Avian flu ban on imports that was implemented late in 2016." Import duties imposed by South Africa have been challenged by the EU and local importers. The outcome of this challenge is yet to be announced. These are the realities that confront the South African government. How it will deal with this issue is yet to be seen. Any adverse decisions taken by South Africa could further injure the South African poultry industry. The government therefore has to tread cautiously and without emotion, in order to find solutions with the EU rather than antagonizing the EU to its own peril.

\section{Should South Africa Shut Down Dumped Chicken Imports to Prevent INDUSTRY COLLAPSE}

The cry from the poultry industry of South Africa is that local producers are efficient and world class but cannot compete in an unfair environment. This cry and other issues are discussed by the author to understand the issue more cogently. The South African chicken industry, a significant portion of the country's maize industry and thousands of jobs are under threat because large quantities of surplus chicken are being dumped in this market by other countries at prices way below their cost of production. Brinkhuis, Pitman and Masemola (2017:7) state that "Thousands of jobs have already been lost and chicken dumping is spreading misery in a country with one of the highest unemployment rates in the world and, where each wage earner supports up to ten people. Almost four years ago, the South African Poultry Association (Sapa) cautioned that 20000 jobs could be lost if imports of cheap chicken continued. At that time it said 5000 jobs had already been shed at large and small producers. Since 2012 eight small medium - sized poultry farms have closed." The trend has continued as the volume of imports has climbed substantially. Producers are being forced into production cuts, jobs are being lost and more are at risk. According to Brinkhuis, Pitman and 
Masemola (2017:7) "The latest estimate is that 1000 jobs will be lost for every 10000 tonnes of dumped chicken imports and therefore, the entire industry is under threat. On the other hand they further state that one of the country's largest chicken producers, RCL Foods, has warned that the dumping could cause the entire South African chicken industry to collapse before the end of 2017. It is estimated that 110000 in the chicken industry and, a further 20000 in the maize and soya industries could lose their jobs. Chicken producers buy nearly half of the country's maize crop and, if the chicken industry fails, the knock - on effect on the grain industry will compound the negative effect."

These imported chicken cuts and pieces as a phenomenon of dumping is against the rules of the World Trade Organization (WTO). As local producers cannot compete with dumped products at artificially low prices, they are left with no option other than to shut down their operations, cut jobs and eventually go out of business. Brinkhuis et al (2017) state that "Imports of chicken have increased by nearly ten times in the past seven years, from 3500 tonnes a month in 2009 to 30000 tonnes a month in the first half of 2016. It has accelerated rapidly in recent years as South Africa remained open to chicken imports when other markets around the world closed. Importers are selling more chicken into the South African market than many of the local producers." It must be clearly understood that this a major government problem because South Africa is being targeted by exporters, particularly those in Europe and South America because, it is one of the few countries that allows virtually unrestricted chicken imports. Russia, formerly a large market, closed its borders to EU imports in 2014 because of a political impasse in relationship to Ukraine and other salient issues, while China has raised tariffs and health barriers to keep imports out. As African countries were targeted, they also implemented a variety of measures to protect their industries. In Ghana according to Brinkhuis et al (2017) "It is one country that did not do so and saw the collapse of its entire poultry industry. This is the danger confronting South Africa as ever larger volumes of chicken imports are dumped into its local market. Dumping therefore raises important issues for South Africa and its policy makers, from unemployment to food security, and has very serious implications for economic and social stability. It is not about globalization, free markets and free trade. Nor is it an issue of an inefficient South African industry being undercut by world - class producers in other countries."

South Africa's modern chicken industry is the fifth most efficient in the world, with production costs well below those in Europe. However, there is almost no country South Africa can export to because all impose technical barriers to block entry. For example, South Africa is not allowed to export poultry to countries in South America because they do not approve South African abattoirs which are world - class in terms of infrastructure, veterinary control and hygiene parameters. For them to approve our abattoirs is a lengthy and unnecessary process that takes years to obtain a clearance veterinary and health certificate. South Africa has to realize that its hands are tied because, it has entered into capitalist agreements and therefore, has placed itself into a no win situation because, we see that other territories such as the US and Europe, state that South African ostriches have bird flu; and although the South African chicken industry has never had avian flu, they use this conjured up argument to block South African exports. It is a nefarious plot on the part of these European and US markets and therefore, South Africa's back is against the wall and, it is held to ransom by the imperatives of vulgar trade which negates free enterprise. The South African government has to look very seriously at these trade agreements and must now put pressure on the WTO or stand outside the imperatives of the World Trade Organization, in its own interests because, it cannot dent South Africa any further, given the almost certain collapse of its poultry industry. The country and the South African government must learn from other African countries, such as Nigeria and Kenya, who have banned all poultry imports because they want to develop their own industries. All these countries understand the importance of food security and jobs. South Africa does not seem to understand and appreciate what it means to look out for our own interests. In other words the EU must be dumped as a partner and we should look at penetrating the African market and, friendly emerging markets and intensify efforts to trade with these countries. It must be understood that we cannot trade against dumped chicken sold way below the cost of production by the EU.

In terms of unfair competition South African producers would compete strongly against imported products if competition was fair, but dumping is not fair competition. It must also be clearly understood that exporters are price takers - they will sell their large surplus of brown - meat leg quarters for what they can get. If tariffs are raised, they will simply accept even lower prices to 
accommodate the increases. And so we see that the local industry contracts and jobs are lost. This in a country where official unemployment jumped to 27 percent in November of 2016, with the broader definition, including the hopeless who have stopped looking for work standing at 36 percent (Other sources place this figures as 42 percent and 45 percent respectively).

Food security also becomes an issue when leading food - producing industries are under threat. Chicken is the major source of protein for the majority of South Africans and has been supplied by local producers. If the local industry collapses and the country rely on imports, that security will be gone. Foreign producers are free to raise prices or switch markets at will when a better business opportunity arises. "Dumping is not even a friend of the poor. Local consumers may briefly enjoy cheaper chicken, but eventually they will have to pay higher prices or go hungry" says Brinkhuis et al (2017). In other words dumping is a destroyer, which is why the South African chicken industry and its thousands of workers need protection, not because the industry cannot compete, but because it is being destroyed by dumping, a practice outlawed by the WTO in word only, as no action is taken against the EU countries that continue with this practice of dumping with continued impunity and bent on destroying the local industry and thus entrenching its desired approach of creating a dependency syndrome against smaller countries like South Africa and, many others within the African continent.

Key players in the industry and labour have initiated discussions according to Brinkhuis et al (2017), "with government to investigate a way forward beyond the insufficient provisional 13.9 percent safeguard duty that was imposed on EU imports in December 2016." South Africa has to act quickly and implement the technical barriers used by other countries in terms of phytosanitary measures, health checks and demands for abattoir certification, that can help protect the South African chicken industry. There can be no argument to this scenario of implementation. Chicken Dumping according to Brinkhuis et al (2017) "Is becoming a national crisis. If nothing is done, the country could have another 130000 jobless people by Christmas of 2017, leaving about 1.3 million family members and other dependents without food or income. The grim prospect is a call to action for the policy makers who can prevent it. The ball is in the court of the ruling and governing party, the African National Congress.

\section{Armyworms Also Threaten South African Crops ANd Maize the Heart of the POULTRY INDUSTRY}

Leading from the discussion undertaken above the autumn armyworms that have ravaged maize fields from Ghana to South Africa since arriving on the continent last year and could ravage and spread to Asia and the Mediterranean. According to the Business Report (2017:1) "South Africa verified that the caterpillars arrived in the continents biggest producer of maize, after travelling from Zambia through Zimbabwe."The pest can devastate fields as the region and South Africa try to emerge from the worst drought in more than 35 years. The poultry industry of South Africa is in great uncertainty in respect of its survival and sustainability is even more compromised than ever before, because of the ravages that can be caused to the maize and other crops of the country. The militant armyworm threatens the livelihood of millions around the world.

The caterpillar destroys young maize plants, attacking their growth points and burrowing into the cobs. This threatens food security in large parts of Africa. It has spread to Malawi, Zambia, Zimbabwe, South Africa, Namibia and Mozambique. There are also reports from Nigeria, Togo and Benin which shows that they are spreading rapidly," reports Kate Kelland (2017:16). It causes major damage, while it affects mainly maize, it has also been recorded eating more than 100 different plant species. This will most certainly dampen the poultry industry of South Africa even further and it can be expected that South Africa will have to import maize giving rise to higher feed prices for poultry. Urgent action is now required by the government to help farmers figure out the best strategies and management techniques required to control the pest. The old adage stands that it never rains but pours. The woes of the South African poultry industry are now in grave territory and in absolute dire straits as it tries to survive. The outbreak of army worm according to Kamcilla Pillay (2017:2) revolves around the following issues:

1. "Hampers drought recovery efforts and farming productivity.

2. The aggregate maize production last year was estimated about 7.7 million tons, down 27 percent from the previous year's already reduced output. 
3. The steep decline was mainly attributed to the El Nino - related drought conditions that curbed white maize yields by 25 percent compared on the 5 year average, while an overall reduction in the area planted also contributed to the smaller harvest.

4. The armyworm could be Spodoptera frugiperda, which is native to South and Central America and also occurs in the Southern States of the US. In South Africa it was first detected destroying maize plants in the provinces of Limpopo and the North West. The North West is an important province in respect of the production of maize and falls within the maize quadrangle of the Republic.

5. The moths are good flyers and wind currents may disperse them over large distances.

6. Farmers have to be given the accurate and continuous technical information about the worm, together with control options by the government.

7. Pheromone traps would be imported into South Africa to determine the exact extent of the spread and the specific strain of worm present.

8. An awareness campaign by the government has been instituted across all provinces.

9. Maize is also the staple diet for most South Africans and, an essential for poultry feed and, is also grown for broad animal feed regimens and therefore, solutions have to be found soon.

10. It would further dampen drought recovery and the prospects for good crop harvests. Maize has been the most affected, as well as other cereals including sorghum, millet and wheat. The entire agricultural industry of South Africa is threatened.

11. The pest can cause damage to the extent of 73 percent of the crop depending on existing conditions and, is difficult to control with a single type of pesticide.

It is therefore essential that the South African government, its Ministry of Agriculture and the commercial agricultural sector of South Africa must enhance capacity to prevent, detect and respond rapidly, to any new pests and disease threat that can bring agriculture and the poultry industry to its feet, with the likelihood of suffering the vagaries of cheap imports of poultry, the continuous importation of maizeand, the insensitivity of human welfare by the capitalist European Union and the USA, including Great Britain.

\section{Higher Import Duties Will Not FiX All the Poultry Sector's Problems}

From the narrative and discussion thus far undertaken in this paper, it is obvious that industry needs to improve cost efficiencies and tackle value - chain dominance by large firms. It cannot be contested that the poultry industry of South Africa, contributes significantly to the economy. In this regard Ratshisusu (2017:13) states that "The poultry industry provides direct and indirect employment for more than 100000 people in the wider poultry value - chain." The poultry Association states that "Almost $38 \mathrm{~kg}$ per capita was consumed in 2014, with beef consumption a distant second at $18 \mathrm{~kg}$ per capita. Poultry meat has also been consistently the most affordable source of animal protein since 2009. However, according to Ratshisusu (2017) "With imported chickens, over the past 12 months the average retail price of frozen chicken portions has increased more than 20 percent despite the corresponding increase in import volumes over the same period, a sign that the local industry is fast losing its competitiveness." On the other hand the pending retrenchment of 1350 employees by RCL Foods, one of the country's biggest poultry producers, is cause for serious concern. This comes after the closure of Mike's Chickens, a family - owned business in the Polokwane, Limpopo Province that was forced to exit the industry in 2016 after 38 years of existence. This resulted in more than 1000 job losses." He further adds that "Country Bird, the third largest broiler producer in the country is going to retrench 1500 employees. This is worrisome to the poultry value - chain."

In South Africa, we also see that local poultry businesses exclude others from participating by not providing the necessary inputs as was seen when Astral Foods prevented Country Bird from gaining access to breeding stock and stopped vertical integration competitiveness in the market. Country Bird subsequently introduced a competing breed after exit agreements were reached with Astral Foods, into the South African market. However, all the challenges were not dealt with. It is thus evident that a strong collaborative effort is required between the government, business and labour to stem the tide 
of job losses and the exit of market participants. Concentrating on import duties and ignoring some of the other challenges, may not provide a long - term solution to ensure the sustainability of the industry. Some of the challenges according to Ratshisusu (2017) are as follows:

- "A constructive, long - term approach to resolving these challenges

- Increasing import duties while ignoring some of the other challenges faced by the local poultry industry producers may not provide a long term solution to ensure the sustainability of the industry.

- The persistent challenges are far more important than import penetration seen by the highly concentrated nature, an outcome of the significant barriers to entry along the entire poultry value - chain.

- The value - chain is dominated by a few large, vertically integrated companies that have the capital required to achieve the economies of scale necessary for a sustainable business operation.

- These firms subsidiaries are active at all levels of the value - chain, from upstream production of animal feed to the downstream of abattoirs, where broilers are slaughtered and processed for consumption - a pre-1994 legacy of apartheid.

- The monopoly of large South African poultry companies has to be broken and prepared for entry by smaller players. This must become a government responsibility after nearly 23 years of freedom and democracy.

- It is therefore not necessary for these large South African companies to cry foul because vertical integration in the domestic poultry industry should and will yield lower production costs and lower prices to consumers, yet this is not the case as EU countries are allowed to dictate and monopolize the South African Poultry industry. This is in many ways is of our own making. And thus this anomaly requires further probing by the government.

- Small market participants that are not vertically integrated are at a distinct disadvantage to bigger competitors because they rely on their major competitors for crucial inputs such as animal feed and breeding stock.

- Industry transformation should also be prioritized. This can be achieved by assisting entrants to the sector to attain economies of scale, which in turn will ensure that they become sustainable competitors in the market.

- Incumbent firms should not just demand protection from the government but provide solutions that would unlock the market structure for these entrants to thrive.

- Supplier - development measures to increase, market access, vertical separation and collaborative research and development initiatives must be introduced, overseen by government and made mandatory."

The cost inefficiencies of producing poultry products in South Africa should be urgently tackled if the industry wishes to secure long - term sustainability. Of critical importance, according to Ratshisusu (2017:13) is "As noted by the University of Johannesburg's Centre for Competition, Regulation and Economic Development, is the high cost of animal feed. The economic inefficiency of local producers implies that the industry will struggle to remain competitive." There therefore, should be willingness from local producers and policy - makers to acknowledge and tackle the challenges the local industry faces on the domestic front urgently and resist the temptation to look only for short - term solutions. Equally where there is dumping of imports the protection of the domestic poultry industry is essential and therefore becomes a necessity.

\section{No GOLD AT THE END OF THE RAINBOW FOR BELEAGUERED CHICKEN INDUSTRY}

Amid layoffs and closures, and a call for a total ban on imports, a task tem is trying to save the poultry sector of South Africa from total collapse, Reports Bongani Mthethwa (2017:6). The narrative looks at the issues involved in this regard and outlines what is being done and what must be done, in order to save the beleaguered poultry industry of South Africa. In this regard the analysis of Mthethwa (2017 and emphasis added by the author) is summarized below as follows: 
- "With rising retrenchments in the poultry industry of South Africa, which is a reality and, further retrenchments are on the cards. RCL Foods pledged R1 million for skills development training for the retrenchment of workers. This is not enough as workers are unable to provide for the needs of their families.

- This does not assist the massive unemployment in the country and therefore, together with poultry companies, government has to come to the party and intervene decisively, in order to fix the ailing industry.

- Chicken imports were raised seven fold over a 14 year period, from 63722 tons in 2001 to 456 794 tons in 2015, and this is frightening, and almost difficult to comprehend. It is therefore imperative that government looks very seriously into the type of agreements entered into with the EU and other countries that are allowed to export chicken and chicken products into the country. These agreements have to be overhauled in the interests of the South African poultry industry.

- A task team has been set up headed by the Department of Trade and Industry, and the chicken crisis is expected to be high on the agenda of the ANC, but the trade unions warned government that 40000 jobs could be lost.

- The ANC said that, it resolved in its meeting that the government should purchase struggling poultry farms and, this was followed by an admission by the DTI during its presentation to parliament that, the poultry industry was in a crisis, which it attributed to consumers' preference for 'brown meat' such as drumsticks and wings.

- Dumping should be challenged in the local courts or at the WTO. (Can this really solve the problem, if agreements have been entered into already?).

- The farms that have been sold to internal buyers must be helped by the government, in order to revive the industry.

- This now provides the government an opportunity to do away with imports. This would create 50 000 direct and indirect local jobs -5 percent of the national target, and that this opportunity can be used to conduct major transformation of the industry.

- Trade instruments are a short - term measure to a long - term problem and that these instruments although urgent, have to be put in place to address the injury caused to the poultry sector because, the industry remains vulnerable and therefore, long - term solutions lie in crafting policy which drives the competitiveness of the sector.

- The avian flu outbreak in the EU would provide the industry with breathing space because only 4 of the 12 eligible EU countries were affected by South Africa's import ban. If this is actioned in a coordinated and sustained manner, we could see a drastic reduction in imports during the course of this ban, and all indications suggest that imports from the EU might be cut by at least half.

- In principle all players within the South African poultry industry agree and, support the industrial policy action plan; incentives targeting the poultry industry and have been asking for a specialized focus on the poultry industry since mid - 2015, when the department was negotiating the African Growth and Opportunity Act poultry deal. In other words AGOA is good but, it also has to be looked into more closely and from a fresh South African perspective." (Bongani Mthethwa, 2017:6; and critique and emphasis added by the author).

It is hoped that after all has been said and done, the DTI - coordinated task team, comes up with frameworks and plans that address issues of cost competitiveness. As things stand today and in the foreseeable future, there seems to be no gold at the end of the rainbow for South Africa's beleaguered chicken industry.

\section{Some OVERAll Conclusions AND RECOMMENDATIONS NOT ONLY FOR THE CHICKEN IndUSTRY BUT THE FUndamental STRUCTURe of THE SOUTH AFrican ECONOMY Must Change: Time to Get Policy Ducks in a Row}

\subsection{Conclusions and Recommendations}

In general something is wrong in the State of South Africa under the current government's policy imperatives after nearly 23 years of democracy and freedom. This is due to a lack of policy coherence and certainty throughout the economy that is saddled with infighting and corruption within the ANC. 
"This has led to the failure to industrialize at the required rate says the country's industrialization tsar Garth Strachan" (In Chris Barron, 2017:9). Government industrialization programmes are barely scratching the surface of South Africa's unemployment rate. Chris Barron summarizes these imperatives and, draws from an interview conducted with Garth Strachan, a Deputy Director General within the Department of Trade and Industry:

- "The government is not creating jobs as quickly or in the scale that is required.

- The lack of policy coherence and programme alignment in government actually is a very big constraint.

- The downside was the unexpected announcement by the beleaguered Eskom Chief Executive who resigned from the state - owned entity because, of his association with capital and the Gupta Family who were accused gravely in the Public Protectors State Capture Report in respect of their business dealings with government and the Banking sector of South Africa. Brian Molefe Torpedoed the government's independent power producer procurement programme last year. $\mathrm{He}$ said that the utility would sign no further agreements to purchase renewable energy from independent power producers. The government has frequently cited South Africa's renewable energy programme as a shining example of how well industrialization is working. This is a falsity and government propaganda to the extreme. It is now in danger of collapsing and shows the incoherence and unreliability of South African policy certainty and implementation.

- All of this will have a devastating effect on foreign investment, the development of local component manufacturing businesses - most of which are black owned or at least BEE compliant, and are involved in job creation.

- It is a critical vehicle for foreign direct investment and is needed to create demand for locally manufactured components in wind and concentrated solar power.

- After Eskom's announcement, SMA, one of the world's largest solar inverter manufacturers shut its factory in Cape Town and, at least three other components manufacturers are likely to follow suit.

- The closure or impending closure of companies in the sector is a matter of great concern. The decision by Eskom has to be reversed.

- Reversing the damage that has been done will not be easy because much of the trust has been lost.

- The independent power producer procurement programme is critically important, and policy alignment has to be secured, which essentially boils down to connecting those producers to the grid. The same applies to the gas industrialization prograame which will be labour intensive and, in this regard policy certainty is essential and also programmes alignment. These issues are or must become non - negotiable.

- There is no doubt that government departments are working against each other and this too scuppers policy certainty. An example of this is the fact that the Department of Home Affairs is wreaking havoc with attempts by the Department of Tourism, to boost what many see as an even more important sector, in terms of potential contribution to GDP than renewable energy.

- It is essential to ensure that there is intra - governmental policy coherence and programme alignment. At the moment there is no -policy alignment in the renewable energy sector and this extends across all sectors.

- If South Africa does not get the alignment of policy, the outcomes of the industrial strategy, which will be job creation, investment, economic growth, exports and so on, will be adversely affected and this has already begun much to the peril of the country which is in a deep economic crisis.

- Industrialization must be geared towards investment and job creation. If this is not done there will be little chance of attracting the necessary foreign investment for it to succeed. In other words policy coherence and programme alignment is non - negotiable. It is one of the prerequisites for 
industrial development. If it is not there, South Africa will be saddled with suboptimal outcomes in mining, agriculture and manufacturing. (The latter two are important also to the beleaguered poultry industry).

- The South African government has been averse to deal with the private sector in an even keel and, has failed to appreciate its importance to the industrialization of the country. This cooperation with the private sector is essential. The government has failed to realize that business leaders won't invest in programmes, if they believe they are likely to be undermined by conflicting political agendas. These agendas are now a hallmark of the political landscape and, bring about an overt lack of policy certainty. This brings about government paralysis which is a feature of the South African government and, ministers are now more concerned about survival than industrialization, for almost a decade under the Zuma Presidency.

- The Trade and Industry Minister speaks with a forked tongue assuring investors that South Africa is a haven for investment. How can the country be open for business when, by his own admission, policy uncertainty and conflicting government agendas are driving investors away.

- There is no doubt that issues of sentiment and political uncertainty are clearly a barrier to a labour - focused industrial strategy.

- State owned enterprises that are owned by the state and are milking cows for politicians, who are top heavy within the Cabinet and, generally inefficient must be looked at such that some could be or need to be privatized. They are loss making enterprises that carry political agendas and scupper sustained and coordinated development of the country. Most of the problems preventing state owned enterprises from playing more effective roles in industrialization have been self - inflicted, rather than the result of global factors.

- Rent seeking behaviour constitutes a serious brake to industrial development and is a major problem in South Africa.

- Companies that want to qualify for government incentives need to raise their competitiveness and must become more labour intensive.

- There needs to be a heavy investment into technology.

- Labour reforms will be necessary to encourage companies to become more labour intensive because with the use of technology fewer staff will be required. (Consider the 4th Industrial Revolution)

- Many economists question whether the government should be in the business of picking winners to throw taxpayers' money at individuals, companies or sectors. Doesn't the market do this more effectively?

- Government has to intervene in respect of market failures" (Chris Barron, 2017:9, Emphasis and added critique by the author).

There is no doubt that South Africa is facing multiple challenges, the most important are the absence of policy coherence and continuity. Domestically, we have to secure policy certainty. There are other enormous challenges: rail and port charges and inefficiencies, electricity and rent seeking, not forgetting the dire straits that the South African poultry industry finds itself in, at the moment, which is on the verge of collapse. These are all obvious barriers to industrialization.

It must be remembered in terms of growth and development, according to Brian Mhlangu (2017:14) that "Any country under normal economic conditions, set economic goals entailed in growth and development plans that, cannot be realistically achieved either in the medium term or long - term, are not worth pursuing. Reduction of poverty in the past 10 years is not due to a more inclusive economy, but to social grants that have brought some relief for the poorest of the poor. It is a mere safety network and also hampers growth an employment opportunities that must be provided by the government." It is easier to believe in the big myth than in the small truth. The situation in South Africa is that the nature and structure of the economy in terms of ownership, management, control and active participation, remains unfairly skewed in favour of a few people against the poor majority of its citizens. This must be squarely placed at the feet of the government, which is in power for nearly 23 
years of democracy. Basically the government is inept and has run out of ideas to positively transform the bleeding economy. This scenario has gone on for almost a decade under the president Zuma presidency.

According to Brian Mhlangu (2017) "This structure has always been exclusive for more than a century and, remains exclusive for more than 50 percent of the population. It can hardly produce inclusive economic growth to the benefit of all citizens. It is due to undesirable outcome of deliberate economic policy design by some to create and produce long - term inequities and therefore, the majority is excluded from the processes of economic production." We believe and indeed our politicians who share in the policy imperatives of these capitalists with their neoliberal policies that, some - day will yield inclusive economic growth for unemployed South Africans, whose number is said to be above 42 percent. As long as the structure of the economy remains untransformed and exclusive to mainly white capital and greedy politicians, amassing wealth at the expense of the poor, there can be no transformation in South Africa, even if the economy grows by 5 percent; the question remains which political and economic policy instruments can be used with responsive results to solve the problem of ownership, management and control of the country's national resources.

Mhlangu (2017) points out that "A fundamental re - engineering of policies cannot be executed successfully by merely paying lip services, using blunt instruments that have been proven to be failures of the ANC government post democracy." Extraordinary measures and at times unpopular choices need to be made by the political and economic leadership, with the courage and commitment to make the economy yield results for all. South Africa's transformation project, as a necessary route to escape the legacy of apartheid witnesses a failure of great magnitude, owing to the inability to progress beyond stagnation to the stage of meeting legitimate demands and expectations. This is the reality under an inept democratic government that has as its sole priority, its own survival at the expense of the population.

\section{Conclusion}

This paper addressed the vexing issue of the collapse of the South African poultry because of the inefficiencies on the part of the South African government, and also discussed some facets of the failure of the industrialization programme, due to the lack of policy coherence, coordination and uncertainty. If these issues are not addressed soon South Africa, will move into a direction where unemployment, inequality and poverty will become the order of the day and, it will become an almost impossible task for the country to emerge from this scenario.

It appears that, the government is looking for answers through divine intervention and, not through the task of governing the country, and in this regard has lost the moral high ground. In other words, it has run out of ideas as was seen by President Zuma's State of the Nation Address delivered to parliament and the nation, on Thursday the $9^{\text {th }}$ of February, 2017. There was nothing in his speech but, populist rhetoric, revolving around the greater distribution of land to the black population, the lack of black participation on the Johannesburg Stock Exchange and all of this was termed radical transformation initiatives in relationship of the sluggish economy, widening inequality and poverty with the inability of the government in creating jobs and stimulating growth, which last year, in terms of growth stood at a meager 0.5 percent and, is projected to grow to 1.3 percent only. It appears that 2017 also will not deliver a growth of more than 1 percent. This is the reality of a country torn asunder by parochial politics of the ruling party, a government that has no idea of how to bring about sustained economic growth and thus usher its people on to a path of economic recovery and lessen the plight of the majority black population who suffered the pangs of apartheid policies and continue to be enslaved by the so - called democratic government.

The vision of the government and its policy imperatives, once again lost the momentum of regaining the moral high ground and was exemplified by a total lack of policy cohesion, coordination and lacked the certainty required to enthuse any confidence in a government that, has lost the plot of what a developmental state means and, as to how to deal with the complexities of the economy and its accompanying grave social issues. No tangible plans were announced in respect of actioning the National Development Plan, which is in the making for nearly a decade and the first phase of implementation, after 5 years remains incomplete and therefore, the reconstruction of the South African health sector, the education sector and other important sectors in general, are in tatters. The 
2017 State of the Nation Address was nothing but rehashing the same imperatives year after year, capturing the same issues. The President failed to provide the nation with the leadership and vision required in dire economic circumstances. No tangible projections in terms of dealing with the ailing economy, no mention of the crisis in the poultry industry was mentioned.

The time has come for the government to bite the bullet towards sound and coordinated strategies in order to bring about policy coherence and sustained coordination, in terms of the growth of the South African economy. If it does not intervene decisively, it will bear the brunt of the electorate in the 2019 national elections.

\section{REFERENCES}

Brian Mhlangu (2017). Fundamental structure of the economy must change. Business Report. Opinion and Analysis. February 1. Page 14. Johannesburg. Republic of South Africa.

Baird, F. (2017). SA poultry industry is facing collapse. Business Report. Opinion and Analysis. February 1. Page 14. Read as Background reading. Johannesburg. Republic of South Africa.

Chris Barron (2017). "Time to get policy ducks in a row." Sunday Times. Business Times. February 5. Page 9. Johannesburg. Republic of South Africa.

Mthethwa, B. (2017). No gold at end of the rainbow for SA's beleaguered chicken industry. Sunday Times. Business Times. February 5, Page 6. Johannesburg. Republic of South Africa.

Ratshisusu, H. (2017). Higher import duties will not fix all the poultry sector's problems. Business Day. January 26. Page 13. Johannesburg. Republic of South Africa.

Kamcilla Pillay (2017). Armyworm outbreak in South Africa: Threat to drought recovery. The Mercury. February 7. Page 2, Durban. Republic of South Africa.

Business Report (2017) Armyworms to spread after African invasion. News in Brief. February 7. Page 1. Johannesburg. Republic of South Africa.

Kate Kelland (2017). Militant armyworm threatens the livelihood of millions around the world. Business Report. February 7. Page 16. Johannesburg. Republic of South Africa.

Mel Frykberg (2017). A pest so destructive it destroys entire farms within a few days. Business Report. February 7. Page 16.Read as Background Reading. Johannesburg. Republic of South Africa.

Brinkhuis, A; Pitman, S; and Masemola, K. (2017). SA must shut down dumped chicken imports to prevent industry collapse. Job Crisis Opinion. Business Day. January 26. Page 7. Johannesburg. Republic of South Africa.

The President of the Republic of South Africa (2017).v State of the Nation Address by Jacob Zuma, President of the Republic of South Africa on the Occasion of the Joint Sitting of Parliament. Issued by the Office of the President. February 9. Pretoria. Republic of South Africa. Read as background Reading.

Shepstone and Wylie Attorneys (2017). Poultry Industry Cries Fowl: The status of import duties on poultry. The Mercury. February 6. Page 7. Durban. Republic of South Africa.

Mark Allix (2017) EU cries foul over chicken crisis claims. Business Day. January 16. Page 10. Johannesburg. Republic of South Africa. Editorial (2017). Poultry industry in a flap. The Mercury. February 3. Page 4. Durban. Republic of South Africa.

Kevin Cowley (2017). Chicken farmers at risk - Davies. Business Report. January 26. Page 18. Johannesburg. Republic of South Africa.

\section{AUTHOR'S BIOGRAPHY}

The Author is a Retired State Veterinarian and Former Deputy Director General of Agriculture and, is currently a Senior Academic and Researcher at the Regent Business School, Durban, Republic of South Africa 